\title{
Socioeconomic Impact of SG 2000 Quality Protein Maize (QPM) Technology Delivery on Beneficiaries in Bauchi and Gombe States
}

\author{
Gizaki, L. J., \\ Department of Agricultural Economics and Extension, \\ Federal University Wukari, Taraba State, Nigeria \\ M. C. Madukwe, \\ Department of Agricultural Extension, \\ University of Nigeria Nsukka, Nigeria
}

Doi: 10.19044/esj.2019.v15n3p169 URL:http://dx.doi.org/10.19044/esj.2019.v15n3p169

\begin{abstract}
The study assessed the impact of SG - 2000 QPM technology adoption on beneficiaries in Bauchi and Gombe States, Nigeria. Specifically, the study sought to determine the socioeconomic characteristics of the beneficiaries, identify beneficiaries sources of information on maize production, assess beneficiaries' perception of the project, assess the impact of QPM technology adoption on the socioeconomic life of beneficiaries and identify constraints encountered by the beneficiaries in technology adoption. Purposive sampling was used in sampling 90 beneficiaries and 90 non- beneficiaries' farmers to give a total of 180 from 10 Local Government Areas where maize is cultivated. The instrument for data collection was a structured interview schedule developed on a 3 - point Likert - type scales. Mean, percentage, $t$ - test and factor analysis were used for data analysis. The study show that the project made a significant $(\mathrm{P} \leq 0.05)$ impact on the project participants in the following socioeconomic possessions: number of milling machine $(\mathrm{t}=$ 11.331), quantity of maize harvested $(\mathrm{t}=2.794)$, number of motorcycle owned $(\mathrm{t}=4.040)$, number of wrist watch owned $(\mathrm{t}=3.861)$, number of associations/clubs belonged $(\mathrm{t}=3.038)$ and the number poultry birds owned $(\mathrm{t}$ $=2.071)$ in Gombe State. While, in Bauchi State, the project made significant $(\mathrm{P} \leq 0.05)$ impact on number of ceiling/fans owned $(\mathrm{t}=2.783)$, number of radios owned $(t=1.08)$, number of television owned $(t=1.457)$ and the number of cattle owned $(t=2.493)$. The major challenges encountered by the beneficiaries in technology adoption were socioeconomic, farm inputs, poor policy support and production related constraints. The study recommended that SG - 2000 QPM technology delivery should ensure timely distribution of inputs such as fertilizers, herbicides and subsidies on farm inputs. In addition,
\end{abstract}


modern farm implements such as tractor should be made available to the beneficiaries to reduce drudgery associated with simple farm tools and to increase farm size per farmer.

Keywords: Sasakawa, Quality Protein Maize, Beneficiaries, Bauchi and Gombe States

\section{Introduction}

\section{Background information}

Nigeria produces a wide range of agricultural commodities, which could serve as raw materials for industrial production and food crop for human consumption. The dual nature of these crops makes them to be in high demand and one of such crop is Maize. Maize (Zea mays) is a cereal crop that grows across a range of agro-ecological zones in Nigeria, though it is grown slightly more in the Northern part of the country. Some of the major producing states in Nigeria includes Adamawa, Bauchi, Borno, Yobe, Jigawa, Gombe, Taraba, Plateau, Sokoto, Kebbi, Katsina, Nasarawa ,Niger and Zamfara http://www.foramfera.com/index.php/membership-zone.

Nigeria has a land area of $98.3 \mathrm{~m}$ hectares and at presents about $34 \mathrm{~m}$ hectares or $48 \%$ are under maize cultivation. With this, one would have thought Nigeria would be self-sufficient in Maize production but the reverse is the case. The country presently produces less than the market demand. It is on record that more than $60 \%$ of Nigeria's production of maize is consumed by the industrial sector for production of flour, beer, malt drink, corn flakes, starch, syrup, dextrose and animal feeds. In order to meet the local demand for the crop, government placed a ban on the export of maize in Nigeria http://www.foramfera.com/index.php/membership-zone.

Sasakawa Global-2000, Nigeria country programme of Sasakawa Arican Association (SAA) is a non-Governmental Organization working in partnership with National and International Research Institutes, Federal and State Ministries of Agriculture, State Agricultural Development Programme, agricultural input organizations and farmers to diffuse improved agricultural technology to farmers in order to increase output. The programme also assist in developing quality extension services through trainings and demonstration and strengthening of linkages amongst research extension services, private sector agricultural organizations and farmers to help farmers raise their productivity. In addition, SG-2000 was to find ways of overcoming the bottlenecks that retard agricultural change, and to help State and Federal agencies involved in agricultural development to strengthen their technology transfer methods. Under the agreement, SG-2000 was to work with government agencies in testing, demonstrating and transferring improved crop production technologies; it was to participate in national field testing and 
demonstrations, and to help multiply seed of better varieties (Valencia and Breth (1999) in SG-2000, 2010).

The SG-2000 strategy in agricultural technology transfer is farmer participatory through Farmer Learning Platforms at community level from planning, implementation, and data collection and reporting. The dissemination of proven crop production technologies is through the establishment of three levels of demonstrations that is Technology Options Plots (TOPs), Voucher Assisted Demonstrations (VADs) and Production Test Plots (PTPs) as farmer Learning Platforms of extension delivery approach (SG-2000, 2010).

In the SG-2000 programme, each extension agent is expected to work with at least 10 farmers, each of whom will have a management training plot. The farmers selected are judged to have leadership qualities and the potential to become a farmer group leader in subsequent years. Participating farmers were expected to be receptive for training and willing to implement the technological package. In the second and subsequent years, 10 additional farmers or more are recruited from each village to expand the program. After a farmer has been in the program for two years he/she is graduated (SG-2000, 2010).

\subsection{Problem statement}

Improvement in technology delivery in Nigeria's agriculture is the veritable means of bringing about improvement in the current levels of agricultural production and resource productivity. However, faced with the increasing need to produce high quality maize products to generate cash income to fulfill basic requirements and improve livelihoods, SG-2000 recognized this need and in partnership with Bauchi State Agricultural Development Programme (BSADP) and Gombe State Agricultural Development Programme (GSADP) introduced quality protein maize (QPM) with enhanced values of amino acids to meet the dietary needs of the Bauchi and Gombe State consumers (both human and animals) through the concepts of technology options plots (TOPs), voucher assisted demonstrations (VADs) and production test plots (PTPs) as farmer learning platforms of extension delivery approach to boost the production of QPM in the two states (SG2000,2010).

Consequently, the questions that now arise are: What is the attitude of these beneficiaries of QPM technology delivery to maize production? What impact did the programme make on their socio economic life? Were there constraints limiting their adoption? It is against this background among others that it becomes pertinent to assess the extent the Sasakawa QPM technology delivery system impacted the beneficiaries in Bauchi and Gombe states of Nigeria. 


\subsection{Purpose of the study}

The broad objective of this study was to assess the socioeconomic impact of SG 2000 maize technology delivery on beneficiaries in Bauchi and Gombe States, Nigeria. Specifically, the study will:

1. Identify the socioeconomic characteristics of the beneficiaries,

2. determine beneficiaries perception about the project

3. assess the impact of QPM technology adoption on the socio economic life of these beneficiaries; and

4. identify constraints encountered by the beneficiaries in technology adoption.

\section{Literature Review}

Agriculture is an important sector of the economy of Nigeria with high potentials for employment generation, food security and poverty reduction. However, these potentials have remained largely untapped. As at 1961, Nigeria was the leading exporter of groundnut with a world's share of $42 \%$. The country also had $27 \%$ of the world's palm oil export, $18 \%$ of cocoa and $1.4 \%$ of cotton as the major West African cotton exporter. This glory however declined over the years; hence the country's dominance in the export of groundnut was taken over by China, United States of America (USA) and Argentina as at 2008 (Federal Ministry of Agriculture and Rural Development, 2011). Indonesia and Malaysia took over in palm oil; Cote d'voire and Ghana also become the leading exporter of cocoa while Mali and Burkina Faso led cotton exports. The competitors maintained their dominance due to strong marketing organizations that linked the farmers to markets and provided support in the form of improved planting materials, fertilizer, credit and rural infrastructure Federal Ministry of Agriculture and Rural Development (FMARD), (2011).

Despite Nigeria's potential competitive advantage - favourable agroecological and natural conditions - in several agricultural commodities (including roots and tubers, cereals and legumes, tree crops and livestock), past and present agricultural policies and programmes have not been able to adequately and significantly address the constraints faced by small-scale farmers. Small-scale farmers in Nigeria are still confronted with, among other problems, poor access to modern inputs and credits, poor agricultural infrastructure, poor extension service, inadequate access to markets, land and environmental degradation (Eboh, Oji, Amakom and Uja 2004).

Besides the government agricultural extension services, some intergovernmental organizations (IGOs), non-governmental organizations (NGOs) and some private sector agencies are operating out-growers' schemes and collaborative advisory services. These are also the local traditional organizations. NGOs in Nigeria are engaged in many activities including 
extension activities on maize production. Examples of such NGOs involved in elaborate maize production extension are the Sasakawa Global 2000 (SG2000) and Farmers Development Union (FADU). Religious organizations such as the Roman Catholics and ECWA Agricultural projects are also active (FMARD, 2012). Other NGOs involved in elaborate maize production extension activities include the West and Central Africa Maize Network (WECAMAN), the International Fund for Agricultural Development (IFAD), United States Agency for International Development (USAID) and the International Institutes for Tropical Agriculture (IITA). Examples of the local traditional organizations are many and well known to need reiteration. These traditional groups promote maize production through their agricultural and community development activities which include inputs distribution, provision of credit facilities and mobilizing the people.

The SG-2000 recommendation was to apply fertilizer a week after planting and again at knee-high stage (top dressing). Some farmers thought the maize plants were spaced too closely and that the recommended fertilizer rate was too low. But farmers who noticed the vigorous maize plants talked to participating farmers and that helped SG-2000 gain credibility. By 1997, as a result of the project's achievements, the Federal Department of Agriculture directed all Nigerian States to adopt the SG-2000 approach (SG-2000, 2010).

However, some officials and researchers were skeptical that farmers would be able to handle the techniques SG-2000 was proposing (Ado in SG2000, 2010). SG-2000 was asking farmers to increase plant population and to incorporate a few grams of fertilizer about 10 or so centimeters from each plant. To make that practical, SG-2000 had simple tin measuring spoons made for the farmers. SG-2000 had to teach the farmers to apply the fertilizer one week after planting and then again about a month later (Elemo, 1993). Extension personnel, researchers, and many farmers considered the process too laborious.

But in the first year, when SG-2000 had only a small number of plots, the farmers who were learning the technology could be closely observed. Those who strayed from the recommendations were dropped, losing the opportunity to buy fertilizer (mainly Urea which was scarce during that time) from the program for the second (top dressing) application. SG-2000 acquired a supply of fertilizers from government and was reselling it to participating farmers at the official subsidized price. That was an incentive for farmers to follow the recommendations because many of them were not able to find fertilizer through official channels and instead had to buy it from the open market (SG-2000, 2010).

Farmers in that first year could observe the differences from maize grown with traditional technology as soon as the maize was about knee high. Maize grown with the recommended technology had more plants per unit area 
and they were green from the bottom to the top of the plant in contrast with neighboring plots where the plants were yellowish, even though farmers conventionally were using higher rates of fertilizer. However, the conventional practice was to apply fertilizer after the plant reached the kneehigh stage and again near tasselling (Kamara, et al, (2012) in SAA, 2012).

Local extension staff were designated by the ADP to work with SG2000 in addition to carrying out their regular duties. Individuals chosen to serve as SG-2000 State or zonal coordinators were seconded to the project by the ADPs. Extension staffs assigned to SG-2000 were selected based on evidence that they were hardworking, honest, and dedicated to improving the wellbeing of farmers (Miko, et.al. 2010). State coordinators supervise zonal coordinators and extension agents and oversee the SG-2000 programme activities with farmers. Zonal coordinators were in charge of the day-to-day activities of SG-2000 within their zones and supervise extension agents work directly with the farmers to ensure that the technological packages are successfully applied (SAA, 2012).

\subsection{Conceptual framework}

In the conceptual framework (Fig. 5), the Sasakawa Global 2000 QPM Project (Block A) has three approached adopted for delivery which is presented in block A1, these are technology options plots (TOPs), voucher assisted demonstrations (VADs) or Women assisted demonstrations (WADs) and production test plots (PTPs) as farmer learning platforms of extension delivery approach to boost the production of QPM. These approaches set out to deliver technologies as site selection technique, improved seed e.g. SGM 1 white \& yellow, MR (white), OBA 98 etc.as land preparation techniques (Block A2). These were the technologies the project aimed to change in the farming pattern of beneficiaries.

The agricultural technology delivery service as an intervention programme of SG-2000 QPM was to ameliorate the conditions of the maize farmers. These beneficiary farmers are small scale maize farmers, women and youth who are into maize farming. These beneficiaries had conditions which necessitated the intervention which includes: their low income, low farm output, low profits from the maize farming, poor livelihood among others, this is presented in block B. These maize farmers condition was what the SG-2000 QPM aimed at to cause a change. It is assumed that these beneficiaries could have only benefit if their perception about the project was favorable. Block $\mathrm{C}$ shows the various ways of response to the project by the target beneficiaries, these responses is first a function of their perception of the project, as well as their submission of interest by way of registering to participate, the block also points at adoption of various technologies of the project introduced. 
There are a number of factors that could also affect the beneficiaries from deriving maximum benefits from the project. These factors can also constrain them from adopting the technologies disseminated. These possible constraints are also presented in Block D, among which includes high cost of labour, non-availability of planting material, poor markets for their farm produce among others.

It is expected that every intervention project should result in changes on the life and situation of the targeted beneficiaries, therefore, from these project beneficiaries, it is also expected that there should have been improvement in their income, profitability from maize farming as a result of improved farm output. This should also result in an improvement in the standard of living of these beneficiaries as well as their livelihood. The project hopes also to improve on the diet quality of both humans and livestock who make use of maize and its products, therefore these changes are all presented in block E. It is expected that changes that occur from the participation of these beneficiaries whether positive or negative will form a basis for planning subsequent projects, this also makes the findings of this study a major asset for future programme planning.

The above parameters would be used in assessing the impact of technology delivery system of the SG-200 protein maize technology delivery systems in Bauchi and Gombe tates, Nigeria. 
A

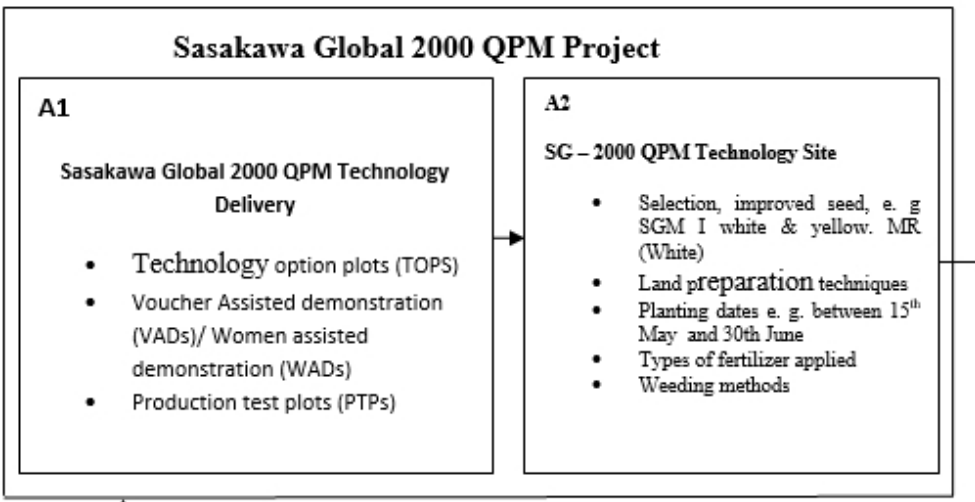

$\mathrm{D}$

Adoptions/Participation

- High cost of labour

- Non availability of planting materials,

- Untimely supply of improved variety,

- Poor access to credit,

- Poor soil fertility,

- Inadequate/poor training contact with extension personnel,

- Poor markets

E

B

\section{Targeted Beneficiaries and their Conditions}

- Small scale maize farmers

- Women and youth in Maize farming

Beneficiaries' Conditions

$\checkmark$ Low income

$\checkmark$ Low output

$\checkmark$ Low profiting from maize

$\checkmark$ Low diets of both humans \& livestock,

$\checkmark$ Poor livelihood

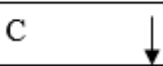

Beneficiaries' Involvement/Participation in the SG 2000 QPM

- Perception of the delivery approach,

- Registration in groups

- Adoption of technologies

- Participation in TOPs or VADs,/ WADs or PTPs

Expected Changes in Beneficiaries' Condition/

Impact of SG 2000 QPM

Improved income,

$\checkmark$ Improved farm output,

$\checkmark$ Higher profiting from maize farming,

$\checkmark$ Improved standard of living,

$\checkmark$ Better diets of both humans \& Livestock,

$\checkmark$ Improvement in farmers' livelihood.

Fig 1: Conceptual frame work for assessing the impact of SG-2000 QPM technology delivery

\section{Methodology}

\subsection{Area of study}

The study was carried out in Bauchi and Gombe states, Nigeria. Bauchi State is located between latitudes $9^{0} 3^{\prime \prime}$ and $12^{0} 3^{\prime \prime}$ north and longitudes $8^{0} 50^{\prime}$ and $11^{\circ}$ east. The number of farm families was 1500,000 with an average size of 11 persons per farm family BSADP, (2013). Bauchi State is agricultural state. Its vast fertile soil is an added advantage for agricultural products, which include maize, rice, millet, groundnut and guineacorn. Irrigation farming is practiced and supported by the use of Fadama and dams for maize and rice 
production. Cattle and other livestock are also reared in the state www.nigeria.com/Nigeria/states_Nigeria/Bauchi_state.html

Gombe is a major food basket in Nigeria. It is located between latitudes $10^{0} 15^{\prime} \mathrm{N} 11010 \mathrm{E}$. The annual temperature ranges from $13^{\circ} \mathrm{C}$ to $30^{\circ} \mathrm{C}$, with an annual average rainfall of $850 \mathrm{~mm}$. Gombe has 2 distinct climates, the dry season (November-March) and the rainy season (April-October). Most of the $20,266 \mathrm{~km}^{2}$ landmass is cultivable. About $60 \%$ of the population is engaged in agriculture. Year round cultivation is possible in some parts of the state due to favourable weather and an extensive irrigation programme (GSAP, 2012).

\section{2 Population and sampling techniques}

All maize farmers in the two (2) states constitute the population for the study. A combination of different sampling procedures were used in selecting the samples to successfully meet the objectives of the study. The states were purposefully selected based on conditions of their agro-ecological suitability for the selected crop. To select representative study sites within the states, use of agricultural zones was employed in Bauchi State while political zoning was used in Gombe State. This is because; the state has no agricultural zones, rather the GSADP makes use of the political zonings. For governmental agency, ADP was purposely chosen because they are the major arm of government extension services in Nigeria used by SG-2000.

From each of the 2 states (Bauchi and Gombe) selected for the study, five (5) LGAs were purposively selected from the three (3) agricultural zones of Bauchi State. Similarly, five (5) LGAs were selected from the three political zones of Gombe State. These LGAs selected are considered to be the high maize producing LGAs in the two states (Shaib, et. al, 2010). The five major maize producing LGAs were: Alkaleri, Bogoro, Ganjuwa, Toro, Jama'are (Bauchi State) and Akko, Balanga, Billiri, Funakaye, Yamaltu Deba (Gombe State) constituting ten (10) LGAs. From each of the 10 LGAs selected, a list of 10 major maize producing villages was obtained. From the list, 3 villages were selected through simple random sampling technique, producing 30 villages for the study (i.e. 3 villages per LGA). From each of the 30 villages sampled, a list of 10 SG -2000 quality protein maize beneficiaries and 10 nonquality protein maize beneficiaries were collected from the farmers' cooperative association of the selected villages through the help of extension workers. Similarly, one beneficiary of TOPs, VADs or WADs and PTPs were also randomly selected respectively, to give a total of 3 QPM beneficiaries per village. Also 3 non-quality protein maize beneficiaries were randomly selected from the list of $10 \mathrm{NSG}-2000$ quality protein maize beneficiaries from each village. Thus a total of 90 SG-2000, QPMBFs and 90 NSG-2000 QPMFs were obtained. The total respondents used for the study were 180. 


\subsection{Data collection and analysis}

Data collected for the study were arranged, coded and analyzed through the use of Statistical Product and Service Solution (SPSS) and STATA computer programmes. Both descriptive and inferential statistical tools were utilized to analyze the data.

Information on the socio-economic characteristics of the respondents were examined. These include:

Farming experience: Farming experience refers to the number of years that respondents have spent in farming. The respondents were asked to give the number of years they had spent in farming.

Farm size: respondents were asked to indicate their farm size in hectares.

Sex: The sex of the respondents recorded at nominal level as male and female. Age of the beneficiaries: respondents were asked to give their ages in years. The actual age in years were later be grouped.

Household size: The respondents were asked to indicate their household size. Educational level: The respondents were asked to indicate their educational level. The categories of the educational levels were scored as follows: No formal education $=1$, primary school attempted $=2$, primary school completed $=3$, secondary school attempted $=4$, secondary school completed $=5$, tertiary education (OND, NCE, HND, and First Degree) =6, higher degrees (M.Sc., Ph.D. $)=7$. Years spent in acquiring formal education will also be asked.

To assess the impact of QPM technology delivery systems on the socio-economic life of the project farmers, before and after was used. The socio-economic impact of the programme on the farmers was measured in terms of what the situation was before and after inception of the programme.

The following variables were examined among others: number of milling machine, quantity of maize harvested and number of motorcycle owned.

To identify the constraints that confronted effective adoption of the innovation by the farmer, a list of possible constraints were made available. Farmers were asked to indicate the level of their perceived seriousness of each constraints on a 3 -point likert type scale ( $3=$ very serious; $2=$ serious; $1=$ not serious. Data was subjected to exploratory factor analysis procedure using principal factor model with varimax rotation in grouping the constraint variables into major constraint factors. In factor analysis, the factor loading under each constraint variable (beta weight) represent a correlation of the variables (constraint areas) to the identified constraint factor and has the same interpretation as any correlation coefficient. However, an only variable with loadings of 0.40 and above (10\% overlapping variance, Comrey, 1962) was used in naming the factor. 
Objectives 1 and 3 were presented using percentage while $\mathrm{t}$ - test and double difference were used for objective 4. Rotated component matrix was used in analyzing objective 5 .

\section{Results and Discussion}

\subsection{Socio-economic characteristics of the respondents}

Sex

Data in Table 1 indicates that greater proportions (67.8\%) of the SG2000 maize technologies delivery participant farmers (PPs) were male, while $32.2 \%$ were female. Also majority (71.6\%) of the non-SG-2000 maize technology delivery participants (PNPs) were male while $28.4 \%$ were female. The pooled data on the same table shows that majority $(69.7 \%)$ of the farmers were male while $30.5 \%$ were female. This implies that more men are involved in maize production in study area. The findings is in line with that of Diran, et. al., (2015) which reported that majority of maize farmers in Bauchi (77.18\%) and Gombe (74.31\%) were male while only 40.86 in Bauchi and 46.71 in Gombe were female. The finding also agreed with that of Fakayode, et. al., (2010) which reported in their study that almost all the households $(95.5 \%)$ of the maize farmers were headed by men while only $5.0 \%$ were female. Oladipo, Ayandiji and Akande (2008) found that 83.3\% male are more involved in maize production than female due to the fact that male are more involved in farming. In line with the findings, Ndaghu, et. al., (2015) also found that men are more involved in maize farming, because of the influence of tradition and religion women are generally restricted to their compounds.

Age

Table 1 shows that a greater proportion $(44.9 \%)$ of the PPs were between 41 and 50 years of age and 8.4\% were between 21 and 30 years of age, $28.7 \%$ were within the age range of 31 and 40 years while only $2.2 \%$ were above the age of 60 years. The mean age of PPs was 44.6 years. This agrees with that of Akeem and Sofoluwe (2012) which reported that the people who are actively involved in the production of maize fall within the ages 41 and 50 years. Also, a greater percentage $(46.1 \%)$ of the PNPs were between the ages of 41 and 50 years, $10.1 \%$ were within the age range of 21 and 30, $27.0 \%$ were within the age range of 31 and 40 years respectively. $15.2 \%$ were within the age range of 51 and 60 years. The mean age of PNPs was 43.3 years. This implies that both farmers were at their middle and productive age hence would be able to carry out tedious operations such as land preparation, planting, weeding, harvesting and threshing of maize and also participate actively SG2000 maize technology project. The finding is in line with that of Mbavi (2013), Idrisa (2009), Kamara (2009), Akadugu, et al. (2012), Mignouna, et al. (2013) which noted in their respective studies that the farming population 
in Northern Nigeria generally is relatively young indicating that there is an active labour force for farming.

\section{Marital status}

Table 1 further shows that majority $(94.4 \%)$ of the PPs were married, while 5.6\% were single. Also, majority (75.6\%) of the PNPs were married, $13.3 \%, 2.2 \%, 7.8 \%$ and $1.1 \%$ were single, divorced, widowed and separated respectively. Pooled data in the same table indicate that majority $(84.9 \%)$ of the farmers were married, while $9.5 \%, 1,1 \%, 3.9 \%$ and $0.6 \%$ were single, divorced, widowed and separated respectively. This result implies that majority of farmers were married, this results agrees with the findings of Adebayo, et. al., (2010) which found that $98.6 \%$ of maize farmers in dry savanna of Nigeria were married. Also, Akeem and Sofoluwe (2012) noted that married households constitute $91.1 \%$ of the total population of maize farmers in Oyo State, Nigeria.

\section{Household size}

Data in Table 1 shows that majority (40.0\%) of the PPs had household sizes of 8 and 12 persons, $27.1 \%$ had 3-7 persons and $17.6 \%$ had $13-17$ persons. Also, $15.3 \%$ had more than 17 persons. Majority $(31.5 \%)$ of the PNPs had household sizes of $8-12$ persons while $20.5 \%, 20.3 \%$ and $19.6 \%$ of them had household sizes of 3-7, 13-17 and above 17 persons respectively. Pooled data in the same table revealed that majority $(36.1 \%)$ of the farmers had household sizes of 8-12 persons, $24.1 \%$ had 3-7 persons, 20.3\% had 13-17 persons and $19.6 \%$ had more than 17 persons. The mean household size was 12 persons per household. Also, Umar, Musa and Kamlang (2014) reported the same average household size of 12 persons among resource-poor maize farmers in Kano and Katsina states. This implies that these farmers had large household size. This had implication on level of dependents and hence the level of poverty in the household since the larger the household size the higher the number of mouths to be feed and vice versa. On the other hand it has positive implication on family labour availability for farming enterprises. This result agrees with the findings of Ogundele and Okoruwa (2006) which noted that household size plays a significant role in subsistence farming in Nigeria where farmers rely on household members for the supply of about $80 \%$ of the farm labour requirement. Also, Jamilu, Abdul-Aziz, Jafaru, Sani and Abudu (2014) reported that household size was an important factor in the adoption of Sasakawa, Global 2000 maize production technology. This was attributed to the fact that SG-2000 method of planting one seed per hole and the fertilizer application methods which entails making of a hole of about $3-5 \mathrm{~cm}$ deep in between the plant stands and the subsequent covering of the hole requires a great deal of labour. Hence, household that have a sizeable number of 
members that are within the productive age would find it easy to carry out such task.

\section{Number of wives}

Table 1 further shows that majority $(41.3 \%)$ of the PNPs had 2 wives, $25.4 \%$ had 1 wife, $22.2 \%$ had 3 wives and $11.1 \%$ had up to 4 wives. Majority (45.8\%) of the PPs had 2 wives, $25.4 \%$ had 1 wife, $18.6 \%$ had 3 wives and only $10.2 \%$ had up to 4 wives. Pooled data in the same table revealed that majority $(43.3 \%$ ) had 2 wives, 25.4 had 1 wife, $20.5 \%$ had 3 wives and the remaining $10.7 \%$ had up to 4 wives. The average number of wives per household head was 2 wives.

\section{Educational level}

Table 1 also reveals that a greater proportion $(36.7 \%)$ of the PNPs completed their secondary education, $14.4 \%$ had no formal education, none $(0.0 \%)$ had adult literacy training, 2.2\% had Koranic education $3.3 \%$ attempted primary school, $15.6 \%$ completed their primary school education, $6.7 \%$ attempted secondary school education, $22.2 \%$ had tertiary education and none $(0.0 \%)$ had higher degrees such as $\mathrm{MSc} / \mathrm{Ph}$. D. For the PPs greater proportion $(40.0 \%$ ) completed their secondary education, $1.1 \%$ had no formal education, 3.3\% had adult literacy training, Koranic education and attempted primary education respectively. Also, $11.1 \%$ completed their primary education, 4.4\% attempted secondary education while $267 \%$ obtained OND/NCE/HND/First Degree certificates. The remaining 3.3\% of them had higher degree certificates. The pooled data shows that majority $(38.7 \%)$ of these farmers' level of education is their completion of secondary education, $7.8 \%$ had no formal education and $1.7 \%$ has adult literacy training while $2.8 \%$ had Koranic and higher degree certificates respectively. Also, 3.3\% only attempted primary school education, $13.3 \%$ completed their primary education, 5.6\% had attempted secondary school and $24.4 \%$ had obtained either OND/NCE/HND/ First degree certificates. This result reveals that most of these farmers have a form of formal education that will increase their ability to obtain process and use information relevant to adoption of the SG-2000 technologies. Education plays a significant role in skill acquisition and technology transfer. It enhances technology adoption and the ability of farmers to plan and take risks. This finding supports the findings of Ogundele and Okoruwa (2006) which reported that farmers with higher levels of education are likely to be more efficient in the use of productive inputs than their counterparts with little or no education. Also, Ephraim, Ted and David (2008) asserted that the adoption of improve maize seed was positively affected by education attainment level of the maize farmers and Jibowo (2000) noted that it is often easier for an educated person to be favourably disposed towards 
improved technologies because such a person could give a reasonable consideration to its adoption.

\section{Farming experience}

Entries in Table 1 reveal that a greater proportion $(53.3 \%)$ of the PNPs had more than 20 years of farming experience, $4.5 \%$ of them have farming experience of between 1-5 years, $15.7 \%$ of them have farming experience of between 6-10years while6.7\% of them have between 11-15 years of farming experience and the remaining $22.5 \%$ had more than 20 years of farming experience. On the other hand half $(50.6 \%)$ of the PPs had more than 20 years of farming experience, $4.4 \%$ have farming experience of between 1-5 years, $8.9 \%$ had farming experience of between $6-10$ years, $15.6 \%$ had between 11 15 years of farming experience while $17.8 \%$ have farming experience of between 16-20 years. The pooled data shows that greater proportion $(52.0 \%)$ of these farmers have more than 20 years of farming experience, $4.5 \%$ of them have farming experience of between 1-5 years, $12.3 \%$ have farming experience of between 6-10 years, $11.2 \%$ have farming experience of between 11-15 years while $20.1 \%$ have farming experience of between 16-20 years. The average years of farming among these farmers were 22.3 years. This implies these farmers have a good number of years of experience in farming which will enable them have managerial ability in terms of managing farm risks and uncertainties such as price fluctuation, disease outbreaks and pest infestation in maize. Farming involves a lot of risks and uncertainties; hence, to be competent enough to handle all the vagaries of farming, a farmer must have stayed on the farm for quite some. This finding is in line with the findings of Bamire, et. al., (2010) which reported that long years of farming enhance the likely adoption of new technologies.

\section{Farm size}

Table 1 also reveals that greater proportion (65.6\%) of the PNPs had farm size ranging from 1-3 hectares, $5.6 \%$ of the farmers had less than 1 hectare of land and $20.0 \%$ of them had farm size ranging from 4-6 hectares while $8.9 \%$ of the remaining farmers had above 7 hectares of land. Also, majority $(82.3 \%)$ of the PPs had farm size ranging from 1-3 hectares, $6.7 \%$ of the farmers had less than 1 hectare of land and $10.0 \%$ of them had farm size ranging from 4-6 hectares while only $1.1 \%$ of the farmers had above 7 hectares of farm size. The pooled data revealed that majority $(73.9 \%)$ of these farmers had farm size ranging from 1-3 hectares, $6.1 \%$ of them had less than 1 hectare while $15.0 \%$ had $4-6$ hectares of land. The remaining $5.0 \%$ of these farmers had above 7 hectares of farm size. The mean total farm size owned by these farmers was 2.6 hectares. This is in agreement with the findings of Ibrahim, Bello and Ibrahim (2009) which reported that the average size of farm land for 
maize production was between 1-2.9 hectares. This finding implies that majority of these farmers in the two states cultivated less than 3 hectares of land which indicates that maize farming in the area is on subsistence level. This farm size is expected to aid the adoption of new technologies by farmers because farmers that lack enough farmland cannot sacrifice their land for trials of a new technology.

\section{Extension contact}

Table 1 also shows that $34.8 \%$ of the PNPs were not visited by any extension agent also $34.8 \%$ indicated that they were visited between 1-2 times within the year under study (2014), 18.8\% had between 3-4 extension contacts within the year under study while $11.6 \%$ of them were visited more than 5 times. On an average the PNPs had only 1 visit within the year. Similarly, more than half $(53.3 \%)$ of the PPs were visited between 1-2 times by any extension agent in 2014, only $18.5 \%$ indicated that they were not visited by any extension agent, $17.3 \%$ of them had 3-4 times extension contacts. The remaining $11.1 \%$ of the PPs had more than 5 times extension visits. The average extension visit for the PPs was 2.7 times within the year. The pooled data shows that majority $(44.7 \%)$ of these farmers were not visited by extension agents in the area, $26.0 \%$ were visited between 1-2 times within the period under study (2014), $18.0 \%$ of them were visited between 3-4 times while the remaining $11.3 \%$ had more than 5 times extension contacts. On the average these farmers were visited about 2 times within the year. This implies that these farmers had a very low extension contact which is approximately once in 6 months which will definitely affects their level of adoption of recommended practices. This finding supports the findings of Ayayi and Solomon (2010), Ede (2011) and Gama (2013) which found that about 50\% of sample farmers were visited by extension agents to disseminate useful information on maize production, among those visited, the average visit was 2 times within a year. This also agrees with the findings of Ajala, Ogunjimi and Farinde (2013) which reported that almost half $(49.7 \%)$ of the respondents did not have contact with extension and also Adesoji (2009) noted that there was low level of extension contact among fish farmers in Osun state. 
Table 1: Percentage distribution of respondents according to socio economic characteristics

\begin{tabular}{|c|c|c|c|c|c|c|}
\hline \multirow[t]{2}{*}{ Variables } & \multicolumn{2}{|c|}{ None Participant } & \multicolumn{2}{|c|}{ Participant } & \multicolumn{2}{|c|}{ Pooled data } \\
\hline & $\begin{array}{l}\text { Percentage } \\
(\%)(\mathbf{n}=90)\end{array}$ & Mean (M) & $\begin{array}{l}\text { Percentage } \\
(\%)(n=90)\end{array}$ & Mean (M) & $\begin{array}{l}\text { Percentage } \\
(\%)(n=180)\end{array}$ & Mean (M) \\
\hline \multicolumn{7}{|l|}{ Farming experience } \\
\hline $1-5$ & 4.5 & & 4.4 & & 4.5 & \\
\hline $6-10$ & 15.7 & & 8.9 & & 12.3 & \\
\hline $11-15$ & 6.7 & 22.4 & 15.6 & 22.2 & 11.2 & 22.3 \\
\hline $16-20$ & 22.5 & & 17.8 & & 20.1 & \\
\hline More than 20 & 53.3 & & 50.6 & & 52.0 & \\
\hline \multicolumn{7}{|l|}{ Farm size (ha) } \\
\hline Less than 1 & 5.6 & & 6.7 & & 6.1 & \\
\hline $1-3$ & 65.6 & & 82.2 & & 73.9 & 2.6 \\
\hline $4-6$ & 20.0 & 3.0 & 10.0 & 2.1 & 15.0 & \\
\hline Above 7 & 8.9 & & 1.1 & & 5.0 & \\
\hline \multicolumn{7}{|l|}{ Number of extension contacts in 2014} \\
\hline None & 34.8 & & 18.5 & & 44.7 & \\
\hline $1-2$ & 34.8 & 1.3 & 53.1 & 2.7 & 26.0 & 2.1 \\
\hline $3-4$ & 18.8 & & 17.3 & & 18.0 & \\
\hline More than 5 & 11.6 & & 11.1 & & 11.3 & \\
\hline \multicolumn{7}{|l|}{ Sex } \\
\hline Male & 71.6 & & 67.8 & & 69.7 & \\
\hline Female & 28.4 & & 32.2 & & 30.3 & \\
\hline \multicolumn{7}{|l|}{ Age (years) } \\
\hline less than 21 & 1.1 & & 0.0 & & 0.6 & \\
\hline $21-30$ & 10.1 & & 6.7 & & 8.4 & \\
\hline $31-40$ & 27.0 & & 30.3 & & 28.7 & \\
\hline $41-50$ & 46.1 & 43.3 & 44.9 & 44.6 & 45.5 & 43.9 \\
\hline $51-60$ & 15.7 & & 13.5 & & 14.6 & \\
\hline above 60 & 0.0 & & 4.5 & & 2.2 & \\
\hline \multicolumn{7}{|l|}{ Marital status } \\
\hline Single & 13.3 & & 5.6 & & 9.5 & \\
\hline Married & 75.6 & & 94.4 & & 84.9 & \\
\hline Divorced & 2.2 & & 0.0 & & 1.1 & \\
\hline Widowed & 7.8 & & 0.0 & & 3.9 & \\
\hline Separated & 1.1 & & 0.0 & & 0.6 & \\
\hline \multicolumn{7}{|l|}{ Household size (number) } \\
\hline $3-7$ & 20.5 & & 27.1 & & 24.1 & \\
\hline $8-12$ & 31.5 & & 40.0 & & 36.1 & \\
\hline $13-17$ & 20.3 & 13 & 17.6 & 12 & 20.3 & 12.0 \\
\hline More than 17 & 19.6 & & 15.3 & & 19.6 & \\
\hline Number of Wives & $(n=63)$ & & $(\mathrm{n}=59)$ & & $(n=122)$ & \\
\hline 1 & 25.4 & & 25.4 & & 25.4 & \\
\hline 2 & 41.3 & 2 & 45.8 & 2 & 43.3 & 2 \\
\hline 3 & 22.2 & & 18.6 & & 20.5 & \\
\hline 4 & 11.1 & & 10.2 & & 10.7 & \\
\hline $\begin{array}{l}\text { Educational level/ Means years spent in } \\
\text { acquiring it }\end{array}$ & & 12.0 & & 12.1 & & 12.1 \\
\hline No formal Education & 14.4 & & 1.1 & & 7.8 & \\
\hline Adult literacy training & 0.0 & & 3.3 & & 1.7 & \\
\hline Koranic education & 2.2 & & 3.3 & & 2.8 & \\
\hline Primary school attempted & 3.3 & & 3.3 & & 3.3 & \\
\hline Primary school completed & 15.6 & & 11.1 & & 13.3 & \\
\hline Sec. school attempted & 6.7 & & 4.4 & & 5.6 & \\
\hline Sec. school completed & 36.7 & & 40.0 & & 38.3 & \\
\hline $\begin{array}{l}\text { Tertiary education (OND/NCE HND/ First } \\
\text { degree }\end{array}$ & 22.2 & & 26.7 & & 24.4 & \\
\hline Higher degrees (MSC/ Ph.D.) & 0.0 & & 5.6 & & 2.8 & \\
\hline
\end{tabular}




\subsection{Knowledge of common practices among SG-2000 QPM farmers and maize farmers}

Table 2 shows the proportion of respondents who gave affirmative response to the various practices as thought by the SG-2000 on the QPM production. The results shows that among the none-participants, majority $(95.6 \%)$ of the none participants were of the opinion that fertilizer use increases maize yield, $75.6 \%$ of the none participant respondents indicated that the use of insecticides and herbicides help in insect and pest control. In addition, a greater proportion of $72.2 \%$ and $65.6 \%$ indicated that low output from maize is associated with poor technology extension visit and that it is easier to produce maize than other cereals like millet, respectively. On the other hand few (14.4\%) of these none participants think that SG-2000 quality protein maize does not support field demonstration/testing programmes of the improved maize technology with small scale farmers, and about a quarter $(24.4 \%)$ of them indicated that in SG-2000 QPM technology delivery, women farmers will not provide the necessary land and labour for VADs plot. This result shows that none participants seem to be more knowledgeable of general maize production information but low on issues related to the SG-2000 project.

While on the side of participants, the results show that almost all $(98.9 \%)$ also opined that fertilizer use increases maize yield, in the same vein majority $97.8 \%, 95.6 \%$ and $82.2 \%$ of these SG-2000 participants shows that SG-2000 quality protein maize enhances farmers in beef fattening, milk and poultry production, the use of insecticides and herbicides help in insect and pest control and that SG-2000 quality protein maize reduces the level of feed fortification with legumes, respectively. Also with great proportion of the SG2000 participants affirming to are the following knowledge statements: SG2000 quality protein maize reduces the level of feed fortification with legumes $(82.2 \%)$, Striga infestation on maize farm is the major constraint affecting output $(80.0 \%)$, in the SG-2000 QPM technology delivery, the plot size for $\mathrm{VAD} / \mathrm{WAD}$ is $1000 \mathrm{sqm}(73.3 \%)$, it is easier to produce maize than other cereals like millet (68.9\%), low output from maize is associated with poor technology extension visit $(61.1 \%)$, the Production Test Plots farmers are expected to source for their inputs, and those with more resources will have the option of growing larger plots of approximately 0.510 ha which is a multiple of the ideal plot (54.4\%) and Technology Option Plots (TOPs) is not learning Plots with multiple training sessions that follows the cropping cycle and culminate with community field days $(51.1 \%)$. On the other side, the participants had the least proportion of them (13.3\%) indicated that SG-2000 QPM does not support field demonstration/testing programmes of improved maize technology with small scale farmers. This results shows that these participants have better knowledge of the SG-2000 programme than they none 
participants, this implies that the participants have a good knowledge of the programme.

The pooled data shows that these respondents have almost all $(97.2 \%)$ of these respondents indicated that fertilizer is used to increase maize yield, while $85.6 \%$ of these respondents indicated that the use of insecticides while $73.3 \%$ of these farmers showed that SG-2000 quality protein maize enhances farmers in beef fattening, milk and poultry production. The result on Table 2 further shows that a greater proportion of these farmers with proportions of $67.2 \%$ and $66.7 \%$ indicated that it is easier to produce maize than other cereals like millet and that low output from maize is associated with poor technology extension visits, respectively. The pooled data showed that the knowledge statement with the least proportion $(13.9 \%)$ of respondents is the perception of SG-2000 QPM as a means of reducing the level of feed fortification with legumes. This results shows that there is a general knowledge of practises that relate to maize production and SG-2000 QPM programme among the respondents, this could be as a result of their several years of involvement and experience in maize production.

Table 2: Percentage distribution of respondents according to their involvements in these practices

\begin{tabular}{|c|c|c|c|}
\hline \multirow[t]{2}{*}{ Knowledge items } & \multicolumn{3}{|c|}{ Percentage (\%) } \\
\hline & $\begin{array}{c}\text { None } \\
\text { Participan } \\
\mathbf{t}(\mathbf{n}=\mathbf{9 0})\end{array}$ & $\begin{array}{l}\text { Participan } \\
\mathbf{t}(\mathbf{n}=90)\end{array}$ & $\begin{array}{c}\text { Pooled } \\
\text { data } \\
(\mathbf{n}=180)\end{array}$ \\
\hline $\begin{array}{l}\text { Does the use of insecticides and herbicides help in insect } \\
\text { and pest control? }\end{array}$ & 75.6 & 95.6 & 85.6 \\
\hline Is fertilizer used for increase in maize yield? & 95.6 & 98.9 & 97.2 \\
\hline $\begin{array}{l}\text { Do you think that SG- } 2000 \text { quality protein maize does not } \\
\text { have potential for improving animal quality feed? }\end{array}$ & 18.9 & 24.4 & 21.7 \\
\hline $\begin{array}{l}\text { Do you think that SG-2000 quality protein maize does not } \\
\text { support field demonstration/testing programmes of } \\
\text { improved maize technology with small scale farmers }\end{array}$ & 14.4 & 13.3 & 13.9 \\
\hline $\begin{array}{l}\text { Do you think that SG- } 2000 \text { quality protein maize reduces } \\
\text { the level of feed fortification with legumes? }\end{array}$ & 30.0 & 82.2 & 56.1 \\
\hline $\begin{array}{l}\text { SG-2000 quality protein maize enhances farmers in beef } \\
\text { fattening, milk and poultry production. }\end{array}$ & 48.9 & 97.8 & 73.3 \\
\hline $\begin{array}{l}\text { Low output from maize is associated with poor technology } \\
\text { extension visit }\end{array}$ & 72.2 & 61.1 & 66.7 \\
\hline It is easier to produce maize than other cereals like millet & 65.6 & 68.9 & 67.2 \\
\hline $\begin{array}{l}\text { Striga infestation on maize farm is the major constraint } \\
\text { affecting output }\end{array}$ & 40.0 & 80.0 & 60.0 \\
\hline $\begin{array}{l}\text { QPM has high prospect of impacting positively on the } \\
\text { Nigerian populace }\end{array}$ & 37.8 & 82.2 & 60.0 \\
\hline $\begin{array}{l}\text { Technology Option Plots (TOPs) is not learning Plots with } \\
\text { multiple training sessions that follows the cropping cycle } \\
\text { and culminate with community field days }\end{array}$ & 30.0 & 51.1 & 40.6 \\
\hline $\begin{array}{l}\text { The TOPs are } 1500 \text { sqm plot and each TOP plot is divided } \\
\text { into the contiguous sub-plots. }\end{array}$ & 38.9 & 64.4 & 51.7 \\
\hline
\end{tabular}


In SG-2000 QPM technology delivery, women farmers will not provide the necessary land and labour for VADs plot In the SG-2000 QPM technology delivery, the plot size for VAD/WAD is 1000 sqm

The Production Test Plots farmers are expected to source for their inputs, and those with more resources will have the option of growing larger plots of approximately 0.510 ha which is a multiple of the ideal plot

$\begin{array}{lll}24.4 & 26.7 & 25.6 \\ 43.3 & 73.3 & 58.3 \\ 44.4 & 54.4 & 49.4\end{array}$

44.4

54.4

49.4

\subsection{Socio-economic impact of SG-2000 maize technology delivery on farmers}

Table 3 shows that in Bauchi state, the SG-2000 made significant impact $(\mathrm{P}<0.05)$ on the project participants in the following socio economic possessions: number of milling machine owned $(\mathrm{t}=11.331)$ quantity of maize harvested ( $\mathrm{t}=-2.794)$, number of motor cycle owned $(\mathrm{t}=-4.040)$, number of cooking stoves owned $(t=3.038)$, number of wrist watch owned $(t=3.861)$, and he number of poultry birds owned $(\mathrm{t}=2.071)$. From all these possessions with significant impact, the number of milling machine owned, number of cooking stoves owned, number of wrist watch owned and poultry birds owned were in favour of the participants while the other two favoured the none participants in Bauchi State. On the other hand, there were no significant $(\mathrm{P}>0.05)$ impact on the socioeconomic possessions of these participants in Bauchi state in the other items such as their maize farm size $(\mathrm{t}=-0.40)$, number of cars owned $(\mathrm{t}=-$ $0.386)$ and number of wives ( $t=-0.381)$ among other fourteen socioeconomic possessions. This shows that SG-2000 made significant impact on the socioeconomic possessions owned among the programme participants than before they joined the project.

The result (Table 3) further shows that in Gombe state, the SG-2000 QPM made significant $(\mathrm{P}<0.05)$ impact on the participants in the following socioeconomic possessions: maize milling machines owned $(\mathrm{t}=3.932)$, number of ceiling/table fans owned $(\mathrm{t}=2.783)$ and the number of cattle owned $(\mathrm{t}=2.493)$ by the participants. All these impacts in the socioeconomic possessions of these participants were in favour of the project participants in Gombe State. On the other hand, the programme did not make significant $(\mathrm{P}>0.05)$ impact on the participants in Gombe state in the other socioeconomic possessions among which includes quantity of maize harvested ( $\mathrm{t}=-1.919)$, amount earned from sales of maize in naira $(\mathrm{t}=-0.645)$ and number of association /clubs they belong to $(\mathrm{t}=1.022)$. The result means that though SG2000 made impact on the socioeconomic possessions of these participants in some areas in Gomber state, there was a better impact on the socioeconomic possessions in Bauchi state than in Gombe State.

The pooled data on Table 3 shows that the SG-2000 QPM programme made significant $(\mathrm{P}<0.05)$ impact on the participants in the following 
socioeconomic possessions: quantity of maize harvested $(\mathrm{t}=2.780)$, number of cooking stoves owned $(\mathrm{t}=2.447)$, number of maize milling machines owned $(\mathrm{t}=8.192)$, number of television owned $(\mathrm{t}=2.471)$, number of wall clock owned $(\mathrm{t}=-2.454)$ and on the number of cattle owned $(\mathrm{t}=2.751)$. All these socioeconomic possessions were in favour of the participants except for the number of wall clock owned. On the other hand, the remaining other socioeconomic possessions did not show any significant impact on the programme participants as shown in pooled data analysed some which includes: number of motor cycle owned $(\mathrm{t}=-1.518)$, number of refrigerators owned $(\mathrm{t}=1.439)$, number of radio owned $(\mathrm{t}=1.060)$, number of furniture owned $(\mathrm{t}=-1.910)$ and number of associations and clubs among others.

This results means that the programme made significant impact on some of the socioeconomic possessions owned by those who participated in such a manner as to improve the number of these possessions. This shows that the SG-2000 QPM was helpful in enhancing the socioeconomic life of participants. This findings on the programme not making significant impact on the number of associations and clubs among the participants did not agree with the findings of Olaolu (2015) who found that Fadama II Critical Ecosystem Management Project made significant impact on the beneficiaries only in the number of associations/ clubs they belong to and the number of ceiling/table fans owned. Even though the beneficiaries tend to have better household possessions, they were not significantly different of better than the non-beneficiaries. Also, the findings of Akinnagbe (2011) does not agree with this findings, where he found that there was a significant difference (11.518; $\mathrm{p} \leq 0.05)$ in the number of association belonged to during the Cocoa Rehabilitation Programmes in 2009 by the GBCFs, NGBCFs, GNGBCFs and NBCFs. The Duncan multiple range tests reveal that, the association belonged to receive by the GBCFs (2.0), NGBCFs (1.0), GNGBCFs (2.0) and NBCFs (1.0) were not statistically different from one another. Also, this area where the project made significant impact could be as a result of the requirement of donor agencies for farmers to be in groups/ association before they can access funds or supports. This is also not in support of the assertion by Njum (2014), who stated that memberships of a farming groups or associations are now prerequisite conditions for farmers to access all government and donor agencies agricultural packages and incentives. 
Table 3: Impact of the SG-2000 on participants' socioeconomic possessions

\begin{tabular}{|c|c|c|c|c|c|c|c|}
\hline \multirow[t]{2}{*}{ Item } & \multicolumn{2}{|c|}{ Before (mean) } & \multicolumn{2}{|c|}{ After(mean) } & \multicolumn{3}{|c|}{$\begin{array}{l}\text { Impact using double difference } \\
\text { (t-values) }\end{array}$} \\
\hline & PNP & PP & PNP & $\mathbf{P P}$ & BAU. & GOM. & Pooled \\
\hline Maize farm size (hectare) & 0.9 & 1.20 & 1.4 & 1.9 & -0.40 & -0.635 & -0.135 \\
\hline $\begin{array}{l}\text { Quantity of maize harvested (No } \\
\text { bags) }\end{array}$ & 259.6 & 902.43 & 523.6 & 2387.8 & $-2.794 *$ & -1.919 & $2.780^{*}$ \\
\hline $\begin{array}{l}\text { How much did you earn in the sale } \\
\text { of maize }(\AA) \text { per bag }(100 \mathrm{~kg}) \text {, } \\
\text { basket, mudus or wheel barrow }\end{array}$ & 90905.8 & 104001.9 & 288919 & 299288 & 0.715 & -0.645 & -0.013 \\
\hline Number of car(s) owned & 1.1 & 1.0 & 1.5 & 1.1 & -0.386 & -1.541 & -0.907 \\
\hline Number of motor cycle owned & 1.1 & 1.1 & 1.3 & 1.4 & $-4.040 *$ & -0.546 & -1.518 \\
\hline Number of Cooking stove owned & 2.2 & 1.6 & 2.5 & 2.2 & $3.038^{*}$ & 0.150 & $2.447 *$ \\
\hline Number of wheel barrow owned & 1.5 & 1.7 & 2.2 & 2.6 & 0.736 & -0.109 & 0.406 \\
\hline Maize milling machine (number) & 1.6 & 1.0 & 0.9 & 1.0 & $11.331 *$ & $3.932^{*}$ & $8.192 *$ \\
\hline Ceiling / Table fan (number) & 3.7 & 2.3 & 7.4 & 4.5 & -0.087 & $2.783^{*}$ & -0.343 \\
\hline Number of wrist watch owned & 1.6 & 1.4 & 1.9 & 1.6 & $3.861 *$ & -0.575 & 0.234 \\
\hline Number of bicycle owned & 1.2 & 1.1 & 1.7 & 1.9 & -0.344 & 1.765 & 0.765 \\
\hline Refrigerators (number) & 1.3 & 1.2 & 1.6 & 1.5 & 0.590 & 1.104 & 1.439 \\
\hline Radio sets (number) & 1.2 & 1.1 & 1.7 & 1.6 & -0.291 & 1.018 & 1.060 \\
\hline Television (number) & 1.3 & 1.3 & 1.6 & 1.6 & -0.745 & 1.457 & $2.471^{*}$ \\
\hline Wall clock (number) & 1.6 & 1.4 & 2.1 & 1.6 & 0.383 & -1.496 & $-2.454 *$ \\
\hline Telephone/ mobile sets (number) & 1.4 & 1.1 & 1.7 & 1.5 & -0.151 & -0.974 & -0.816 \\
\hline Number of association/club & 1.1 & 1.2 & 1.4 & 1.6 & -1.033 & 1.022 & 0.958 \\
\hline Furniture (number) & 3.7 & 2.9 & 6.3 & 5.3 & -0.304 & -1.447 & -1.910 \\
\hline Number of wives & 1.6 & 1.6 & 2.2 & 2.3 & -0.381 & -0.361 & -0.647 \\
\hline \multicolumn{8}{|l|}{$\begin{array}{l}\text { Number of livestock possessed } \\
\text { (a) Goats/sheep }\end{array}$} \\
\hline (b) Cattle & 10.8 & 12.4 & 7.8 & 19.3 & -0.784 & 0.073 & -0.790 \\
\hline (c) Poultry & 4.8 & 4.0 & 5.7 & 7.8 & 1.238 & $2.493^{*}$ & $2.751^{*}$ \\
\hline \multirow[t]{2}{*}{ (d) Pigs } & 21.8 & 24.5 & 21.0 & 66.7 & $2.071^{*}$ & -0.697 & -0.425 \\
\hline & 0.0 & 9.0 & 0.0 & 21.0 & 1.44 & 000 & 0.272 \\
\hline
\end{tabular}

4.4 Impact on maize farmers' type of house, standard of living, type of toilet facilities being used and sources of drinking water Nature of house lived

Table 4 shows that there were significant changes $\left(\chi^{2}=60.10, P=0.000\right.$ and $\left.\chi^{2}=41.083, \mathrm{P}=0.00\right)$ in the proportion of programme participants (PPs), and Programme none participants (PNPs), respectively, on the nature of house they lived in before the period of the inception of the programme and after. This can be seen as majority $(64.0 \%)$ of the PP were living in mud houses with corrugated iron sheet roof in 2008, and only a greater proportion (49.4\%) still lives in mud houses with corrugated iron sheet roof in 2014, and a higher 
proportion (29.2\%) instead of the $4.5 \%$ in 2014 live in concrete houses with corrugated iron sheets among the PPs. The situation is similar among the PNPs as $21.3 \%$ of them now stay in concrete houses with corrugated iron sheets as against the $9.0 \%$ of them.

A further test of association between the nature of house the participant and none participants live in by 2014 shows that there is no significant $\left(\chi^{2}\right.$ $=5.947, \mathrm{P}=0.745$ ) association between the two. This shows that the changes among the participants after the programme is not the same with that of the none participants, and this difference is in favour of the participants as they seem to have better quality of house after the programme than those of the none participants. This could imply that the SG-2000 QPM has not enhanced the nature of houses participants live in than the period before the programme.

\section{Standard of living}

Data in Table 4 shows that there were significant changes $\left(\chi^{2}=12.67\right.$, $\mathrm{P}=0.049$ and $\left.\chi^{2}=19.554, \mathrm{P}=0.021\right)$ in the proportion of the PPs and PNPs, respectively, in the standard of living before and after the commencement of the project, while no significant $\left(\chi^{2}=3.762, \mathrm{P}=0.926\right)$ existed in the standard of living among the participants and none participants. Also greater proportions (51.7\% and 50.0\%) of the PPs and PNPs, respectively had their standard of living as good as others in 2008, but by 2014, majority (71.9\%) of the participant became better than others and a greater proportion $(46.6 \%)$ also became better than others. This implies that there is significant changes in the standard of living of the PPs and PNPs (from same as others to better than others). Table 14 also shows that there is no significant changes $\left(\chi^{2}=3.762\right.$, $\mathrm{P}=0.926)$ in the living standards of PPs and PNPs after the commencement of the programme. This implies that the changes in the standard of living of PPs after the commencement of the programme is not significantly associated with that of none participants, which seems to be in favour of the participants. This could imply that the programme had no positive impact on improved standard of living of the PPs. This finding is not in line/ agreement with the findings of Nwalieji (2014) who found that the project studied had positive impact on improved standard of living of the participants. Also this finding also disagrees with Alabi, Ogbonna, Lawal and Awoyinka (2014) who noted that Fadama II project greatly enhanced the income of the beneficiaries, thereby raising their standard of living, had expansion in their business and increased their productity.

\section{Toilet facilities used}

Table 4 shows that there were significant changes $\left(\chi^{2}=15.519\right.$, $\mathrm{P}=0.004$ and $\chi^{2}=22.411, \mathrm{P}=0.00$ ) in the proportion of programme participants (PP), and Programme none participants (PNP), respectively, on the toilet 
facilities they make use of before the period of the inception of the programme and after. This can be seen as majority (58.4\%) of the PP used pit toilets in 2008, and also a majority (58.4\%) still used pit toilets in 2014, and a higher proportion $(37.1 \%$ ) instead of the $6.7 \%$ in 2014 now use water system toilet facility among the PP. The situation is similar among the PNPs as a greater proportion $(46.0 \%)$ of them used bush systems as against the $63.2 \%$ of them that now use pit toilets.

A further test of association between the toilet facility the participant and none participants used by 2014 shows that there is no significant $\left(\chi^{2}\right.$ $=7.471, \mathrm{P}=0.963$ ) association between the two. This shows that the changes among the participants after the programme is not the same with that of the none participants, and this difference is in favour of the participants as they seem to have better toilet facility after the programme than those of the none participants. This could imply that the SG-2000 QPM has not enhanced the toilet facility participants use than the period before the programme.

\section{Sources of drinking water}

Table 4 shows that there were significant changes $\left(\chi^{2}=27.127\right.$, $\mathrm{P}=0.007$ and $\left.\chi^{2}=39.040, \mathrm{P}=0.00\right)$ in the proportion of programme participants (PP), and Programme none participants (PNP), respectively, on the sources of drinking water of before the period of the inception of the programme and after. This can be seen as a greater proportion (47.7\%) of the PP used sourced water from streams in 2008, and majority (52.3\%) source drinking water from dug wells in 2014, and a greater proportion (41.6\%) instead of the $7.9 \%$ in 2008 now (2014) source their drinking water from dug wells among the PNPs.

A further test of association between the sources of drinking water between the participant and none participants in 2014 shows that there is no significant $\left(\chi^{2}=16.791, \mathrm{P}=0.158\right)$ association between the two. This shows that the changes among the participants after the programme is not the same with that of the none participants, and this difference is in favour of the participants as they seem to have better source of water after the programme than those of the none participants. This could imply that the SG-2000 QPM has not enhanced the sources of drinking water participants' use than the period before the programme. 
Table 4: Changes in maize farmers' type of house, standard of living, type of toilet facilities being used and sources of drinking water

\begin{tabular}{|c|c|c|c|c|c|c|c|}
\hline \multirow[t]{2}{*}{ Item } & \multicolumn{3}{|c|}{ PP } & \multicolumn{3}{|c|}{ PNP } & \multirow{2}{*}{$\begin{array}{c}\text { PP\&PN } \\
\text { P 2014 } \\
\chi^{2} \text { Value }\end{array}$} \\
\hline & $\begin{array}{l}2008 \\
\%\end{array}$ & $\begin{array}{l}2014 \\
\% \\
\end{array}$ & $\chi^{2}$ Value & $\begin{array}{l}2008 \\
\%\end{array}$ & $\begin{array}{l}2014 \\
\%\end{array}$ & $\chi^{2}$ Value & \\
\hline \multicolumn{8}{|l|}{ Nature of House } \\
\hline Thatched mud house & 28.1 & 10.1 & 60.10 & 43.8 & 15.7 & 41.083 & 5.947 \\
\hline $\begin{array}{l}\text { Mud house with } \\
\text { corrugated iron sheet roof }\end{array}$ & 64.0 & 49.4 & $(0.000)$ & 47.2 & 57.3 & $(0.000)$ & $(0.745)$ \\
\hline $\begin{array}{l}\text { Concrete house with } \\
\text { corrugated iron sheets }\end{array}$ & 4.5 & 29.2 & & 9.0 & 21.3 & & \\
\hline $\begin{array}{l}\text { Concrete house } \\
\text { with aluminum sheet }\end{array}$ & 3.4 & 11.2 & & 0.0 & 5.6 & & \\
\hline \multicolumn{8}{|l|}{$\begin{array}{l}\text { Standard of living as } \\
\text { compared with others }\end{array}$} \\
\hline Worse than others & 24.7 & 1.1 & 12.67 & 42.0 & 5.7 & 19.554 & 3.762 \\
\hline As good as others & 51.7 & 25.8 & $(0.049)$ & 50.0 & 42.0 & $(0.021)$ & $(0.926)$ \\
\hline Better than other & 23.6 & 71.9 & & 6.8 & 46.6 & & \\
\hline No difference & 0.0 & 1.1 & & 1.1 & 5.7 & & \\
\hline \multicolumn{8}{|l|}{ Toilet facilities used } \\
\hline Bush system & 34.8 & 4.5 & 15.519 & 46.0 & 2.3 & 22.411 & 7.471 \\
\hline Pit toilet & 58.4 & 58.4 & $(0.004)$ & 37.9 & 63.2 & $(0.000)$ & $(0.963)$ \\
\hline Water system & 6.7 & 37.1 & & 16.1 & 34.5 & & \\
\hline \multicolumn{8}{|c|}{ Sources of your drinking water } \\
\hline Rain water & 23.9 & 1.1 & 27.127 & 48.3 & 0.0 & 39.040 & 16.791 \\
\hline Stream water & 47.7 & 5.7 & $(0.007)$ & 36.0 & 19.1 & $(0.000)$ & $(0.158)$ \\
\hline Dug well & 20.5 & 52.3 & & 7.9 & 41.6 & & \\
\hline Bore holes & 8.0 & 35.2 & & 7.9 & 33.7 & & \\
\hline Pipe borne water & 0.0 & 5.70 & & 0.0 & 5.6 & & \\
\hline
\end{tabular}

4.5 Farmer identified factors militating against the implementation of the SG-2000 QPM technology delivery

Table 5 shows the results of the rotated factor matrix indicating the extracted factors based on the responses of the project beneficiaries farmers on the constraints in implementing the project. It is evident from the table that there four major factors affecting the project beneficiaries. Factors 1, 2, 3 and 4 were named socio-economic constraints, farm input constraints, poor policy support and farm production constraints.

Under the socio-economic, the specific constraining variables to the SG-2000 QPM technology delivery included: difficulty in marketing maize products (.657), inadequate fund for to start up (.699), difficulty in obtaining credit (.787), inadequate land for massive maize production (.714), inadequate improved processing machinery (.700), late supply of farm inputs by SG-2000 (.559) and low income from QPM (.468). This implies that the project implementation had problems that were related to difficulty in obtaining credit, land and processing facilities. This agrees with the findings of Fabiyi, Danladi, Akande and Mahmood (2007) which stated that lack of credit 
facilities (88\%), land problem (83\%), late farm input delivery (50\%) were ranked as first, second and third respectively as major constraints limiting the performance of farmers in maize production in Gombe state.

Farm inputs constraints included poor access to improve maize seed variety (.648), poor access to fertilizer (.814), poor access to herbicide (.776), poor access to insecticides (.817) and unavailability of labour (.459). This means that the farmers would have enjoyed higher crop output if the intervention of the SG-2000 maize technology delivery project was free from these problems. Although, the farmers had access to fertilizer, herbicide, insecticide and labour for improved maize technology to some extent, these factors still pose some challenges in the smooth implementation of the SG2000 recommendations. Full access to fertilizer, herbicides, insecticides and efficient marketing of maize products with adequate source of labour will bring about their full participation in the technology delivery. These findings are similar to that of Adesiyan (2015) which observed that land use in hectares, labour in man-days, quantity of fertilizer, herbicide, insecticides and maize seed are significant factors affecting maize output in the study area. All were positive and significant factors affecting maize output in Ilesa at 5\% level.

Variables that loaded under factor 3 poor policiessupport included poor extension visit to farmers (.586), inconsistent government policies(.794)and religious belief system (.788). This finding on poor policy support with respect to extension visit, family pressure and belief system which hinders more especially women into active participation in the SG-2000 QPM production is a serious challenge to the implementation of the WADs training programme. Women would enjoy the intervention of the project better if there are no bottlenecks to their active participation.

Farm production factors included difficulty in carrying out recommended practices (.724), literacy level of the farmers (.405), difficulty in forming cooperatives (.536), and transportation problem (.429). This finding on difficulty in carrying out SG-2000 QPM recommendation with respect to farmers' literacy level is in line with the findings of Idrisa, Ogunbameru and Shehu (2012) which reported that there was a positive and significant relationship between level of education and extent of adoption among maize farmers in Gwoza Local Government Area. The influence of education on adoption is more likely to prevail in economies where farming communities are being exposed to educational opportunities, compared to economies where almost all farmers have attained the understanding and utilization of agricultural technologies (Asfaw and Admassie, 2004). Also, enrollment into cooperative association would enable these maize farmers to enjoy more assistance from the SG-2000 QPM project, since the project had dealings with only registered farmers. 
Table 5: Rotated component matrix of programme beneficiaries' perception of problems to effective implementation of the project in Bauchi and Gombe state

\begin{tabular}{|c|c|c|c|c|}
\hline & \multicolumn{4}{|c|}{ Component } \\
\hline & 1 & 2 & 3 & 4 \\
\hline Poor extension visit to farmers & -.153 & .385 & -.586 & .330 \\
\hline Poor access to improve maize seed variety & -.126 & 648 & -.308 & .269 \\
\hline High cost of technology introduced & .393 & .317 & -.316 & .275 \\
\hline Difficulty in carrying out recommended practices & .370 & -.105 & -.257 & .724 \\
\hline Poor access to fertilizer & .276 & .814 & .019 & -.010 \\
\hline Poor access to herbicide & .196 & .776 & .137 & .091 \\
\hline Poor access to insecticides & .255 & .817 & .146 & .052 \\
\hline Difficulty in marketing products & .657 & -.166 & -.005 & .210 \\
\hline Inadequate fund for start-up & 699 & .272 & -.091 & .034 \\
\hline Difficulty in obtaining credit & .787 & .151 & -.038 & -.040 \\
\hline Inadequate land for massive maize production & .714 & .192 & .250 & -.049 \\
\hline Inadequate improved processing machinery & .700 & .049 & .081 & .297 \\
\hline Late supply of farm machinery by SG-2000 & .559 & .132 & -.233 & -.121 \\
\hline Climate variability & -.223 & -.529 & -.006 & .482 \\
\hline Literacy level of the farmers & .036 & .389 & .248 & .405 \\
\hline Inconsistent government policies & -.086 & .143 & .794 & .159 \\
\hline Religious belief system & -.045 & .084 & .788 & -.045 \\
\hline Difficulty in forming cooperatives & .017 & .003 & .064 & .536 \\
\hline Family pressure on women & .080 & .072 & -.046 & .429 \\
\hline High interest rate on credit & .663 & .426 & -.104 & -.074 \\
\hline Problem of striga infestation & -.069 & -.160 & -.114 & -.157 \\
\hline Unavailability of labour & .156 & .459 & -.054 & -.201 \\
\hline Low income from maize harvested products & .468 & .225 & .084 & .220 \\
\hline Centralization of training centers for TOPs, VADs and WADs & .373 & .293 & .055 & -.398 \\
\hline
\end{tabular}

Extraction Method: Principal Component Analysis.

Rotation Method: Varimax with Kaiser Normalization.

a. Rotation converged in 8 iterations.

\section{Conclusion and recommendation}

In conclusion the SG-2000 maize technology delivery made an appreciable impact on number of milling machine owned, quantity of maize harvested, number of motor cycle owned, number of cooking stoves owned, number of wrist watch owned and number of poultry birds owned of the programme participants. The SG-2000 also made impact on the socioeconomic possessions of these participants in some areas in Gombe State, there was a better impact on the socioeconomic possessions in Bauchi State than Gombe state. Difficulty in carrying out recommended practices, poor access to fertilizer, difficulty in marketing maize produce, inadequate fund for start-up, inadequate land for massive maize production, inadequate modern processing machinery, late supply of farm inputs by the SG-2000, climate variability, religious belief system, difficulty in forming cooperative, transportation problem, high interest rate on credit, problem of striga infestation and low income from maize compared to other agricultural 
products were major constraints encountered by the programme participants. Therefore, to enhance maize production in the two states, modern farm implements such as tractor should be used to reduce drudgery associated with simple farm tools and to increase size per farmer. There should be timely (before the farming season kick off) and adequate supply of agro-input such as fertilizer, herbicides, etc. by the service providers. This would discourage farmers from relying on high cost of privately sold agro-input such as fertilizers. SG-2000 programme which aimed at enhancing farmers output as well as marketing alongside the provision of farmers' input supply should have input supply incentives in the form of subsidized inputs. The programme also builds links with commodity markets as part of the programme design. This will help to take care of some facility problems faced by the farmers.

\section{References:}

1. Adebayo, S. B., Tahirou, A., Diakalia, S., Augustine, L. (2010): Characterization of Maize Producing Households in the Dry Savanna of Nigeria. IITA Research to Nourish Africa. Also available at: http://www.iita.org/c/document_library/get_file?uuid.

2. Adesiyan, A. T. (2015): Economic Analysis of Maize Production in Osun State: A Case Study of Ilesa East and West of Osun State. Journal of Economic and Sustainable Development 6(9) pp. 268-272.

3. Adesoji, S. A. (2009): Assessment of Fish Farming Management Practices in Osun State, Nigeria. Unpublished Ph. D. Thesis, Obafemi Awolowo University. pp. 4-10.

4. Ajala, A. O., Ogunjimi, S. I., Farinde, A. J. (2013): Assessment of Extension Service Delivery on Improved Cassava Technologies among Cassava Farmers in Osun State, Nigeria. International Journal of Applied Agricultural and Apicultural Research 9(1\&2) pp. 71-80.

5. Akadugu, M. A., Guo, E., Dadzie, S. K. (2012): Adoption of Modern Agricultural Production Technologies by Farm Households in Ghana. What Factors Influence their Decisions? Journal of Biology, Agriculture and Healthcare 2(3).pp. 12-20.

6. Akeem, T., Sofoluwe, N. (2012): Assessment of Farm Level Pesticide among Maize Farmers in Oyo State, Nigeria. Journal of Food Science and Quality Management vol.13.

7. Akinnagbe, O.M (2011): Evaluation of Government and NonGovernmental Agencies CocoaResuscitation Programmes inSouthwestern Nigeria, a PhD Thesis Presented at the Department of Agricultural Extension, University of Nigeria, Nsukka. pp 81-153.

8. Ayayi, M. T., Solomon, O. (2010): Influence of Extension Contact and Farmers Socio-Economic Characteristics on Adoption of Oil Palm 
Technology in Aniocha North Local Government Area, Delta State, Nigeria.

9. Bamire, S. A., Abdoulaye, T., Amaza, P., Tegbaru, A., Alene, A> D., Kamara, A. Y. (2010): Impact of Promoting Sustainable Agriculture in Borno (PROSAB) Programme Adoption of Improved Crop Varieties in Borno State of Nigeria. Journal of Food, Agriculture and Environment 8(3\&4) pp.391-398.

10. Eboh, E. C., O. K. Oji, O. G. Oji, U. S. Amakom and O. C. Ujah. (2004): Towards the ECOWAS Common Agricultural Policy Framework: Nigeria Case Study and Regional Analysis. Report submitted to Associates for International Resources and Development (AIRD), Cambridge, USA, for USAID/WEST AFRICA.

11. Ephraim, N. Ted, S., David, N. (2008): Factors Affecting Adoption of Improved Maize Seed and Fertilizer in Northern Tanzania.

12. Elemo, K.A. (1993): Maize Agronomy Research in the Nigerian Savanna. Approaches to Improving Maize Technology Delivery Systems in Nigeria.Proceedings of National Quality Protein Maize Production Workshop $4^{\text {th }}-5^{\text {th }}$ September 2001 at Institutes for Agricultural Research Conference Hall ABU, Zaria.

13. Fabiyi, E. F., Danladi, B. B., Akande, K. E., Mahmood, Y. (2007): Role of Women in Agricultural Development and their Constraints in Billiri Local Governemnt Area, Gombe State, Nigeria. Pakistan Journal of Nutrition 6(6) pp.676-680.

14. Fakayode, S. B., Omotesho, O. A., Olorunsanya, E., Babatunde, R. O., Obafemi, A. A. (2015): Economic Assessment of Fadama Maize Production in Kwara State, Nigeria. Available at http://unilorin.edu.ng/.../Economic\%20Assessment\%20of20Fadama $\% 20 \ldots$

15. Federal Ministry of Agriculture and Rural Development (FMARD) (2011): Agricultural Transformation Agenda: We Will Grow Nigeria's Agricultural Sector. A Draft Report for Discussion. http://www.foramfera.com/index.php/membership-zone

16. Ibrahim, H., Bello, M. (2009): Food Security and Resource Allocation among Farming Households in the North Central Nigeria. Pakistan Journal of Nutrition 8(8) pp. 1235-1239.

17. Idrisa, Y. (2009): Analysis of the Determinant of Soybean Production Technology Adoption by Farmers in Southern Borno State. Unpublished Ph. D. Dissertation Submitted to the School of Postgraduate Studies, University of Maiduguri, Borno-Nigeria.

18. Idrisa, Y. L., Ogunbameru, B. O., Shehu, H. (2012): Effects of Adoption of Improved Maize Seed on Household Food Security in 
Gwaza Local Government Area of Borno State, Nigeria. Agricultural Science Research Journals 2(2) pp.70-76.

19. IITA, (2012): Maize crop. Downloaded from website: http://www.iita.org/maize

20. Jamilu, A. A., Abdul-Aziz, H., Jafaru, A. K., Sani, B. M., Abudu, S. (2014):

21. Factors Influencing the Adoption of Sasakawa Global 2000 Maize Production Technologies among Smallholder Farmers in Kaduna State. Journal of Agricultural Extension 18(1) pp. 62-72. Also available online at: http://dx.doi.org/10.4314/jae.v18i/.6.

22. Kamara, A. Y., Ewansiha, S. U., Menkir, A. Tofa, A. I., (2012): Agronomic Response of Drought-Tolerant and Striga-Resistant Maize Cultivars to Nitrogen Fertilization in the Nigerian Guinea Savannas. Maydica 57.114-120.

23. Mbavi, J. J. (2013): An Assessment of the Effectiveness of the Sudan Savanna Taskforce Project in Adoption and Diffusion of Improved Cowpea Varieties in Selected Communities in Musawa Local Government Area of Katsina State. An M.Ed. Unpublished Thesis Submitted to the Department of Adult Education and Community Services, Faculty of Education, Bayero University Kano.

24. Miko, S., J. A. Valencia, A. M. Falaki (2010): Maize for Better Nutrition. The Challenges in the Coming Millennium, Proceedings of the National Maize Production Workshop SG2000/IAR/FMRD/ADPs, $222^{\text {nd }}-24^{\text {th }}$ July, 1999 p. ii.

25. Ndaghu, N. N., zakari, A., Shehu, A., Tahirou, A. (2015): Socioeconomic Factors Affecting Adoption of Early Maturing Maize Varieties by Small Scale Farmers in Safana Local Government Area of Katsina State, Nigeria. Journal of Development and Agricultural Economics 7(8). pp.274-282. Also available at: http://www.academicjournals.org/JDAE

26. Nwalieji, H. U. (2014): Assessment of the United States Agency for International Development Rice (Oryza Sativa) Project Phase one in Anambra and Ebonyi States, Nigeria. A Ph. D. research Findings Seminar Presented in the Department of Agricultural Extension, University of Nigeria, Nsukka, Enugu State.

27. Ogundele, O. O. Okoruwa, V. O. (2006): Technical Efficiency Differentials in Rice Production Technologies in Nigeria. AERC research Paper 154. African Economic Research Consortium, Nairobi. http://www.aercrafrica.org/documents/RP154.pdf.

28. Oladipo, F. O., Ayandiji, A., Akande, M. (2008): The Roles of Youth in Maize Production in Surulere Local Government Area, Oyo State, Nigeria. International Journal of Agricultural Economics and Rural 
Development 1(1).pp 47-52.Also available at: http://www.ijaerd./autechaee.edu.com

29. Olaolu, M. O., Akinnagbe, O. M. (2014): Constraints and Strategies for Improving Agricultural Intervention Programme in Nigeria: A Case Study of National Fadama Development Project Phase II in Kogi State. Journal of Agricultural Extension 18(2) pp.88-94.

30. Sasakawa African Association (2010): Monitoring, Evaluation, Learning and Sharing (Theme 5). Available at http://www.saasafe.org/www/nigeria html

31. Sasakawa African Association (2012). Strategic Plan, 2012-2016. Available at http://www.saa-safe-org/fr/strategic plan_Plan_2012

32. SG-2000 (2010): Nigeria Project. A Simplified Guide for Crop Production Practices in Nigeria.

33. USDA, (2010): Foreign Agricultural Service Global Agriculture Information Network, Nigeria Grain and Feed Annual Report.

34. USDA, (2012): Nigeria Grain and Feed Annual Report. Downloaded from website: http://www.thebioenergysite.com/report

35. Valencia, J. A. and Breth, S. A. (1999): Maize Technology Transfer. The Sasakawa Global 2000 experience in Nigeria. In: Valencia et. al. (ed). Sustainable Maize Production in Nigeria: The Challenges in the Coming Millennium. Proceedings of the National Maize Production Workshop SG2000/IAR/FMRD/ADPs, 222 ${ }^{\text {nd }}-24^{\text {th }}$ July, 1999 pp. 1323. 